\title{
ДИНАМИКА РАЗВИТИЯ ПОНИМАНИЯ В ОБУЧЕНИИ
}

\begin{abstract}
Аннотация. В статье представлены размышления о продвижении студентов в процессуальном поле понимания в границах трех сфер человеческого бытия и традиций исследования субъекта - когнитивной, герменевтической и экзистенциальной. Осмыслены такие феномены как понимание-знание, понимание-интерпретация, понимание-постижение в процессе обучения студентов. На основании анализа междисциплинарных исследований в статье представлен текст, подлежащий толкованию, как основная содержательная единица гуманитарной образовательной деятельности, обладающая значительным потенциалом при развитии понимания в обучении студентов вуза. В центре внимания находятся теоретические особенности, специфика и характеристика работы студентов с текстом с целью продвижения в процессуальном поле понимания. Разработана теоретическая модель динамики продвижения студентов в прочессуальном поле понимания и выделены эмпирические критерии данного процесса. Показано, что в науке накоплен определенный потенциал для разработки теоретико-методологических и прикладных аспектов проблемы формирования и развития понимания в обучении. Результаты анализа существующих источников научной информации и новые, авторские подходы позволили выявить высокую актуальность проблематики развития понимания в обучении и острую необходимость практической реализации концептуальных подходов известных отечественных психологов в обучении студентов.

Ключевые слова: традиции исследования субъекта, когнитивная сфера бытия, герменевтическая сфера бытия, экзистенциальная сфера бытия, текстовая природа знания, понимание-знание, понимание-интерпретация, понимание-постижение, понимание-проблематизация контекста, процессуальное поле понимания.
\end{abstract}

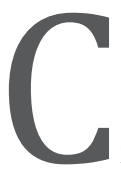

овременное российское общество, актуализирующее человека как ценность, изменяет систему целеполагания обучения и содержания высшего профессионального образования, усиливает личностную ориентацию в содержании и технологиях, способствует становлению творческой и развивающей направленности человека в обучении.

В современных условиях заданы новые ориентиры для неклассической психологии личности: «от жизнедеятельности к жизнетворчеству; от смысловой регуляции к регулированию смыслов, от психологии «изменяющейся личности в изменяющемся мире» - к психологии личности, творящей и изменяющей себя и свой жизненный мир ${ }^{1}$. Именно данные направления достаточно непротиворечиво определяют современные традиции исследования субъек-

1 Леонтьев Д.А. Психология смысла: природа, строение и динамика смысловой реальности. 2-е, испр. изд. М.: Смысл, 2003. C. 444. та: когнитивную, герменевтическую и экзистенциальную.

Трем сферам человеческого бытия и традициям исследования субъекта - когнитивной, герменевтической и экзистенциальной соответствуют три типа понимания проблем, способов, явлений, и событий окружающего мира: понимание-знание, понимание-интерпретация, понимание-постижение (В.В. Знаков). Данные типы понимания образуют континуум продвижения студента в процессуальном поле понимания.

Рассматривая особенности динамики продвижения студентов в процессуальном поле понимания в экзистенциальной реальности мира, в границах герменевтического типа реальности, в когнитивном типе реальности нами осуществлен сущностный учет фактора человека в противовес конъюнктурному декларированию важности этого фактора. «Тело текста» без продуцирующего или воспринимающего его человека остается некоторой мертвой последовательностью графем; для его «оживления» или «одушевления» необходима 


\section{Потенциал интеллекта}

включенность и «тела текста», и индивида в соответствующую культуру, вне которой текст как таковой состояться не может» ${ }^{2}$. Так, в когнитивном mune реальности определены отношения «Человек - Предмет», в границах герменевтического muna реальности осуществляется взаимодействие «Человек - Смысл», в экзистенциальной реальности мира в центре внимания оказывается «Человек - Мир». Сущностные отношения в когнитивном тune реальности ориентированы на то, чтобы научно-предметные знания были направлены на усвоение практических навыков и действий общекультурного или производственного характера. В границах герменевтического типа реальности рождаются смыслы текстов, расшифровки значений речевых, культурных практик, связанных с психологической реконструкцией духовного мира людей. В экзистенциальном типе реальности реализуется соотношение, раскрывающее, с одной стороны предметность культуры, с дугой - внутренние, сущностные силы человека. Рассматривая данное соотношение, В.И. Слободчиков и Е.И. Исаев подчеркивают, что «природа и общество, являясь фундаментальными предпосылками становления человека, не становятся прямо содержательными характеристиками ни самой его личности, ни его мира; они всегда имеют ценностную валентность и конкретно-исторический облик, обнаруживают себя перед человеком как вполне определенные канонические бормы культуры, для приобщения к которым всегда необходим посредник, в качестве которого может выступить знак, слово, символ, миф, Другой» ${ }^{3}$. Именно таким посредником в психологии понимания в обучении студентов вуза является текстовая природа социально-гуманитарного знания.

На основании анализа исследований в области философии, литературоведения, языкознания, психолингвистики, семиотики нами был представлен текст, подлежащий толкованию, как основная содержательная единица гуманитарной образовательной деятельности, обладающая значительным потенциалом при развитии понимания в обучении студентов вуза. Особенности, специфика и

\footnotetext{
2 Залевская А.А. Текст и его понимание. Тверь: Тверской государственный университет, 2001. С. 157.

3 Слободчиков В.И., Исаев Е.И. Основы психологической антропологии. Психология развития человека: Развитие субъективной реальности в онтогенезе: учебное пособие для вузов. М.: Школьная пресса, 2000. С. 126.
}

характеристика работы студентов с текстом с целью продвижения в процессуальном поле понимания будут находиться в центре данной статьи.

На основе установления соотношений учебных задач с когнитивным типом реальности понимание-знание отражает специфику функционирования существующей образовательной среды вуза, не способствующей полноценной самореализации студентов в процессуальном поле понимания. Соответственно, данный процесс накопления научно-предметных знаний происходит спонтанно, интуитивно, а, следовательно, как правило, неэффективно, что свидетельствует о недостаточном использовании внутренних возможностей студента и культурно-образовательной среды вузов. Тем не менее, нами не отрицается значение получаемых знаний, но акцент при этом делается на умениях приобретать, понимать, перерабатывать и использовать полученные знания в условиях собственной жизнедеятельности.

На основе установления соотношений учебных задач с герменевтическим типом реальности в процессе понимания-интерпретации смыслы текстов, расшифровки значений речевых, культурных практик требуют приведения к некоторому гармоничному состоянию «онтологических, феноменологических, деятельностных аспектов анализа смысловой реальности» (Д.А. Леонтьев). Вместе с тем за понятием смысла стоит «сложная многогранная смысловая реальность, принимающая различные формы и проявляющаяся в различных психологических эффектах» ${ }^{4}$.

В экзистенциальной реальности мира типичным является понимание-постижение событий и ситуаций человеческого бытия (В.В. Знаков), специфичных для человека способов бытия в мире, основанных на осознаваемом или неосознаваемом выборе возможностей существования.

В рамках проводимого нами научно-исследовательского курса на развитие понимания в обучении студентов вуза реализуется возможность становления речевых новообразований ранней юности, среди которых могут быть выделены умения, направленные на то, чтобы комплексно и осознанно проводить терминологизацию и детерминологизацию, метафоризацию и деметафоризацию текста (в терминологии А.Ф. За-

Леонтьев Д.А. Психология смысла: природа, строение и динамика смысловой реальности. 2-е, испр. изд. М.: Смысл, 2003. C. 105. 
кировой), концептуализацию и деконцептуализацию текста, и на этой основе онтологизацию и деонтологизацию способов бытия человека в современном социуме.

Как правило, умение осуществлять терминологизацию и детерминологизацию текста в границах эмпирического типа мышления достаточно продуктивно развивается на основе установления соотношений учебных задач с когнитивным типом реальности, где с необходимостью осуществляется понимание-знание. Умение осуществлять метафоризацию и деметафоризацию, концептуализацию и деконцептуализацию текста в границах перехода от эмпирического мышления к теоретическому мышлению, как правило, успешно развивается на основе установления соотношений учебных задач с герменевтическим типом реальности, где с необходимостью осуществляется понимание-интерпретация. Умение осуществлять на этой основе онтологизацию и деонтологизацию способов бытия человека в современном социуме достаточно продуктивно развивается на основе установления соотношений учебных задач с экзистенциальным типом реальности, где с необходимостью осуществляется пониманиепостижение.

В индивидуальной деятельности студента наиболее значимыми для формирования понимания являются следующие познавательные процедуры: понимание-узнавание (узнавание знакомого в новом материале), понимание-гипотеза (прогнозирование, выдвижение гипотез о прошлом или будущем объекта, ситуации, которую необходимо понять) и понимание-объединение (объединение элементов понимаемого в целое) ${ }^{5}$. Кроме того, необходимо задействовать еще одну познавательную процедуру, получившую развитие в нашем исследовании - «понимание-проблематизация контекста» (включение систем значений и смыслов, на основе которых строится образ мира человека, собственные способы бытия) ${ }^{6}$.

Эти познавательные процедуры могут рассматриваться как предпосылки и условия поэтапного,

\footnotetext{
Знаков В.В. Понимание в мышлении, общении, человеческом бытии. М.: Изд-во «Институт психологии РАН», 2007. C. 55-59.

6 Борзова Т.В. Теоретические основы понимания в обучении. Хабаровск: Изд-во Дальневосточ. гос. гуманит. ун-та, 2013. C. 46.
}

динамичного продвижения студента в процессуальном поле понимания ${ }^{7}$.

Понимание-узнавание как познавательная процедура реализуется в границах когнитивного muna реальности на основе следующих способов работы с текстами: построение эмпирических вопросов, проведение текстового ассоциативного эксперимента, подведение под понятие, построение социального узуса способов бытия человека в социуме, вычленение доминирующей темы текста, составление рекомендаций, применение децентрации как процесса изменения личностной позиции студента при анализе текста.

Реализации познавательных процедур понимания-гипотезы и понимания-объединения в границах герменевтического типа реальности способствуют следующие способы работы с текстами: построение вопросительного высказывания, теоретических вопросов, скрытых вопросов, моделирование научного текста, применение собственно герменевтических приемов понимания («истина-неистина», «герменевтический круг» и др.).

Реализации познавательной процедуры noнимание-проблематизация контекста в границах экзистенциального типа реальности способствуют следующие способы работы с текстами: развитие вероятностного прогнозирования при анализе методологического текста, сближение денотативного и коннотативного фона текста, построение собственной модели бытия человека в социуме, создание нарративного текста.

На основе установления соотношений учебных задач с когнитивным типом реальности осуществлению понимания-знания способствуют следующие виды учебных текстов, подлежащие усвоению на основе научных понятий: учебный текст, отрывок из художественного произведения; полное художественное произведение и т.д. (Границы подобного разделения текстов здесь и далее весьма условны).

На основе установления соотношений учебных задач с герменевтическим типом реальности осуществлению понимания-интерпретации способствуют следующие виды текстов, подлежащие усвоению на основе научных понятий: авторская теоретическая интерпретация

Борзова Т.В. Понимание как методологическая проблема социально-гуманитарных наук // Мир науки, культуры, образования. 2012. № 5 (36). С. 5. 


\section{Потенциал интеллекта}

результатов психологических тестов, вызывающая выполнение студентом собственного анализа той или иной методики по специально разработанному нами плану; категориальный аппарат психолого-педагогических, философских дисциплин, подлежащих пониманию в образовательном процессе; самостоятельно подбираемый личностью литературный материал или материал научного плана и т.д.

В экзистенциальной реальности мира типичным является понимание-постижение событий и ситуаций человеческого бытия (В.В. Знаков), специфичных для человека способов бытия в мире, основанных на осознаваемом или неосознаваемом выборе возможностей существования. На основе установления соотношений учебных задач с экзистенциальным типом реальности пониманиепостижение с необходимостью включает в себя научный текст, методологический текст, нарративный текст, описание глубоко переживаемых значимых жизненных событий, которыми бы человек обязательно хотел бы поделиться с окружающими людьми.

При этом детерминантами развития в когнитивном типе реальности является вербально-демонстрационное объяснение в виде трансляции, запоминания и воспроизведения текстов, подлежащих толкованию. В границах герменевтического muna реальности на основе работы с текстом, осуществляется регулирование смыслов бытия. В экзистенциальном типе реальности реализуется рождение способов бытия, а ориентиры неклассической психологии в экзистенциальной сфере бытия определяют вектор развития человека «от психологии «изменяющейся личности в изменяющемся мире»-к психологии личности, творящей и изменяющей себя и свой жизненный мир». «Практика образования призвана обеспечить:

1) ... образование, позволяющее личности выстраивать жизненную перспективу в соответствии со своими возможностями и желаниями;

2) овладение учащимися современным уровнем предметных знаний и теоретическим мышлением в предметной действительности;

3) развитие деятельностных способностей..., освоение учащимися обобщенных способов действий, лежащих в основе высоких форм деятельности современного человека - исследования, проектирования, конструирования, организации и управления;
4) возможности перехода учащихся к индивидуальным образовательным программам и программам самообразования» ${ }^{8}$.

Иными словами, структурные компоненты когнитивного и герменевтического типов реальности в логико-аналитическом описании признаков и характеристик являются важнейшими составляющими экзистенциального тuпa и без перехода одного типа в другой, без развития и взаимного обогащения собственных структурных компонентов различных сфер текстового бытия человека невозможна его качественная динамика продвижения в процессуальном поле понимания.

«В действительности в многомерном мире человека реальности нередко настолько взаимосвязаны, что их трудно расчленить, отделить одну от другой» 9 . Однако трудность различения реальностей не означает, что это различение нельзя и не нужно осуществлять. Напротив, на первых ступенях психологического анализа сложных проблем мира человека всегда необходима аналитическая ясность, хотя она и чревата упрощением предмета исследования. Это в полной мере касается соотношения реальностей, их понимания учеными, а также соотношения типов привлекаемых для этого знаний ${ }^{10}$. Как и всякая другая, картина динамики продвижения студентов в процессуальном поле понимания, носит условный характер, позволяя, однако, рассматривать условия развития человека через значимые, объективно существующие и реально взаимодействующие факторы. Представленные сферы бытия имеют свои константы и отражают специфику психологии понимания в обучении студентов вуза в контексте значений и смыслов, придаваемых когнитивной, герменевтической и экзистенциальной сферам бытия в конкретный исторический момент.

Реальность образно-знаковых систем, представленная в таблице ниже, «это особенная форма существования человеческой сущности, особые условия движения человека к себе (разр. моя. - Т.Б.) как личности» ${ }^{11}$.

\footnotetext{
8 Слободчиков В.И. Антропологические перспективы отечественного образования. Екатеринбург: Информационноиздательский отдел Екатеринбургской епархии, 2010.

9 Знаков В.В. Понимание в мышлении, общении, человеческом бытии. М.: Изд-во «Институт психологии РАН», 2007. С. 19.

10 Там же.

11 Мухина В.С. Личность: Мифы и Реальность (Альтернативный взгляд. Системный подход. Инновационные аспекты). Екатеринбург: ИнтелФлай, 2007. С. 143.
} 
Определение возможной динамики продвижения студентов в процессуальном поле понимания с необходимостью требует выделения эмпирических критериев, по которым можно было бы судить о переходе студента из одной сферы бытия в другую при толковании различного рода текстов, подлежащих пониманию в процессе обучения.

Рассмотрение эмпирических критериев когнитивного и герменевтического, экзистенциального типов реальности в логико-аналитическом описании признаков и характеристик, эффектов «встроенности» структурных компонентов понимания в данные типы реальности обусловлено методологическими основаниями, представленными в трудах таких исследователей, как В.В. Знаков, изучающего понимание в мышлении, общении, человеческом бытии ${ }^{12}$; А.А. Залевская, представляющая понимание текста как процесс построения его проекции реципиентом в русле интегративного подхода к реальному функционированию языка при взаимодействии комплекса психических процессов человека, с учетом роли слова как средства доступа к единой информационной базе человека - его образу мира ${ }^{13}$; А.Ф. Закирова, исследующая теоретико-методологические основы и практику педагогической герменевтики ${ }^{14}$; В.С. Мухина, анализирующая условия, предпосылки и механизмы развития и бытия личности, структуру ее самосознания и внутреннюю позицию, показывая, как в недрах идеополей общественного сознания формируются и трансформируются мифы и реальности представлений о человеке как о личности, в частности, в сфере реальности образно-знаковых систем ${ }^{15}$; М.А. Холодная, исследующая психологию понятийного мышления: от концептуальных структур до понятийных способностей (семантических, категориальных, концептуальных) ${ }^{16}$ и др.

12 Знаков В.В. Понимание в мышлении, общении, человеческом бытии. М.: Изд-во «Институт психологии РАН», 2007. $479 \mathrm{c}$.

13 Залевская А.А. Текст и его понимание. Тверь: Тверской государственный университет, 2001. 177 с.

14 Закирова А.Ф. Теоретико-методологические основы и практика педагогической герменевтики. Дисс. ... докт. пед. наук. Тюмень, 2001.

15 Мухина В.С. Личность: Мифы и Реальность (Альтернативный взгляд. Системный подход. Инновационные аспекты). Екатеринбург: ИнтелФлай, 2007. 1072 с.

16 Холодная М.А. Психология понятийного мышления: От концептуальных структур к понятийным способностям. М.: Изд-во «Институт психологии РАН», 2012. 288 с.
Особенности организации и функционирования структурных компонентов каждой из сфер бытия «задают» свойства экзистенциальной сферы бытия (Рис. 1).

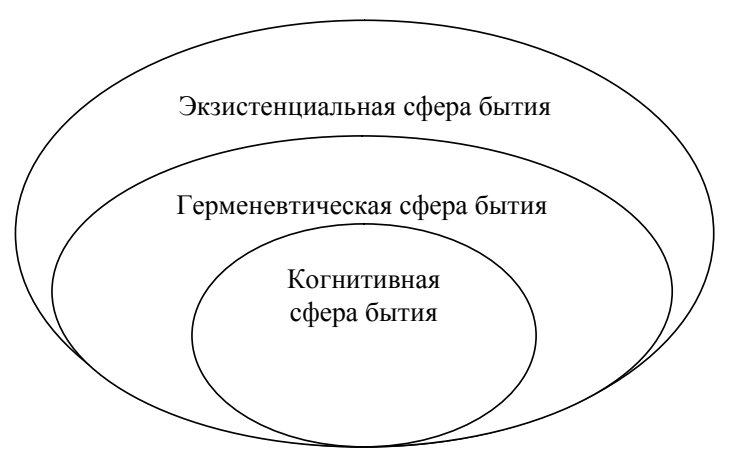

Рис. 1. Эффекты «встроенности» структурных компонентов понимания в сферы бытия человека

С другой стороны, в целом образованная сфера бытия человека в процессуальном поле понимания определяет функционирование когнитивной и герменевтической сфер. При этом, чем более качественными по своему наполнению являются герменевтическая и когнитивная сферы бытия, тем более продуктивно функционирует экзистенциальная сфера и наоборот, чем менее качественными по своему наполнению являются герменевтическая и когнитивная сферы бытия, тем менее продуктивно функционирует экзистенциальная сфера бытия человека.

Кроме того, необходимо отметить при рассмотрении исторического ракурса изучаемой проблемы, что проблема реальностей бытия всегда волновала и будет волновать умы исследователей разных эпох.

Так, В.С. Мухина выделяет пять реальностей существования человека: 1 - реальность предметного мира; 2 - реальность образно-знаковых систем; 3 - реальность социально-нормативного пространства; 4 - природная реальность; 5 - реальность внутреннего пространства личности ${ }^{17}$.

Особый интерес, в проводимом нами исследовании, занимает реальность образно-знаковых систем. Согласно концепции В.С. Мухиной, реальность образно-знаковых систем, сложившихся во всей истории человечества, «имеет фундаментальное значение для человека как личности: именно

17 Мухина В.С. Личность: Мифы и Реальность (Альтернативный взгляд. Системный подход. Инновационные аспекты). Екатеринбург: ИнтелФлай, 2007. С. 48-143. 
Динамика продвижения студентов в процессуальном поле понимания

Табл. 1.

\begin{tabular}{|c|c|c|c|}
\hline Сфера бытия & Когнитивная & Герменевтическая & Экзистенциальная \\
\hline Объект развития & Человек - предмет & Человек - смысл & Человек - мир \\
\hline $\begin{array}{l}\text { Структура } \\
\text { объекта }\end{array}$ & $\begin{array}{c}\text { Научно-предметные знания - } \\
\text { усвоение практических навыков } \\
\text { и действий общекультурного или } \\
\text { производственного характера }\end{array}$ & $\begin{array}{c}\text { Смыслы текстов, расшифровки } \\
\text { знаний речевых, культурных прак- } \\
\text { тик - реконструкция } \\
\text { духовного мира человека } \\
\end{array}$ & $\begin{array}{c}\text { Предметность культуры - } \\
\text { внутренний мир, сущностные } \\
\text { силы человека }\end{array}$ \\
\hline $\begin{array}{l}\text { Предпосылки } \\
\text { и условия }\end{array}$ & Понимание - узнавание & $\begin{array}{c}\text { Понимание - гипотеза, } \\
\text { понимание - объединение }\end{array}$ & $\begin{array}{c}\text { Понимание - проблематизация } \\
\text { контекста }\end{array}$ \\
\hline $\begin{array}{l}\text { Базовые } \\
\text { процессы }\end{array}$ & $\begin{array}{c}\text { Эмпирическое мышление } \\
\text { в форме терминологизации - } \\
\text { детерминологизации }\end{array}$ & $\begin{array}{c}\text { Переход от эмпирического мыш- } \\
\text { ления к теоретическому в форме } \\
\text { метафоризации - дематофориза- } \\
\text { ции, концептуализации - } \\
\text { деконцептуализации } \\
\end{array}$ & $\begin{array}{c}\text { Теоретическое мышление } \\
\text { в форме онтологизации - } \\
\text { деонтологизации }\end{array}$ \\
\hline $\begin{array}{c}\text { Детерминанты } \\
\text { развития }\end{array}$ & $\begin{array}{c}\text { Вербально-демонстрациональное } \\
\text { объяснение в виде трансляции, } \\
\text { запоминания и воспроизведения } \\
\text { текстов, подлежащих толкованию }\end{array}$ & Регуляция смыслов & Рождение способов бытия \\
\hline $\begin{array}{c}\text { Механизмы } \\
\text { и движущие } \\
\text { силы }\end{array}$ & $\begin{array}{l}\text { Текстовый ассоциативный экспе- } \\
\text { римент, постановка эмпирического } \\
\text { вопроса, подведение под понятие. }\end{array}$ & $\begin{array}{c}\text { Моделирование текста, постро- } \\
\text { ение вопросительного высказы- } \\
\text { вания, применение герменевти- } \\
\text { ческих приемов «истина»-«не } \\
\text { истина», «герменевтический круг» }\end{array}$ & $\begin{array}{c}\text { Сближение денотативного и конно- } \\
\text { тативного фона текста, построение } \\
\text { вероятностного прогнозирования, } \\
\text { постановка теоретических вопросов, } \\
\text { построение нарративных текстов }\end{array}$ \\
\hline $\begin{array}{l}\text { Результат } \\
\text { развития }\end{array}$ & Понимание - знание & Понимание - интерпретация & Понимание - постижение \\
\hline
\end{tabular}

\section{Эмпирические критерии понимания когнитивной сферы бытия}

Табл. 2.

\begin{tabular}{|c|c|c|c|c|c|c|}
\hline \multirow[b]{2}{*}{$\begin{array}{c}\text { Этапы } \\
\text { обучения }\end{array}$} & \multicolumn{6}{|c|}{ Эмпирические критерии } \\
\hline & $\begin{array}{c}\text { Оперирование } \\
\text { содержанием } \\
\text { вербальных } \\
\text { знаков в рамках } \\
\text { индивидуально- } \\
\text { го ментального } \\
\text { лексикона }\end{array}$ & $\begin{array}{c}\text { Установление } \\
\text { эмпирического } \\
\text { характера свобод- } \\
\text { ных и направлен- } \\
\text { ных словесных } \\
\text { ассоциаций }\end{array}$ & $\begin{array}{c}\text { Установление харак- } \\
\text { тера переработки } \\
\text { словесно-логической } \\
\text { информации, до- } \\
\text { пускающего опытную } \\
\text { проверку }\end{array}$ & $\begin{array}{c}\text { Осуществление } \\
\text { актов наимено- } \\
\text { вания } \\
\text { (выражение } \\
\text { своего опыта в } \\
\text { словах) }\end{array}$ & $\begin{array}{c}\text { Постановка } \\
\text { вопросов, } \\
\text { носящий эм- } \\
\text { пирический } \\
\text { характер }\end{array}$ & $\begin{array}{c}\text { Осуществление } \\
\text { вербально-демостра- } \\
\text { ционного объяснения } \\
\text { в виде трансляции, } \\
\text { запоминания и вос- } \\
\text { произведения текстов }\end{array}$ \\
\hline
\end{tabular}

Табл. 3.

\section{Эмпирические критерии понимания герменевтической сферы бытия}

\begin{tabular}{|c|c|c|c|c|c|c|}
\hline \multirow[b]{2}{*}{$\begin{array}{c}\text { Этапы } \\
\text { обучения }\end{array}$} & \multicolumn{6}{|c|}{ Эмпирические критерии } \\
\hline & $\begin{array}{c}\text { Мысленное пере- } \\
\text { мещение предмета } \\
\text { понимания в такие } \\
\text { условия, в которых } \\
\text { его сущность рас- } \\
\text { крывается с особой } \\
\text { определенностью }\end{array}$ & $\begin{array}{c}\text { Предмет пони- } \\
\text { мания стано- } \\
\text { вится объектом } \\
\text { последующих } \\
\text { мысленных } \\
\text { трансформаций }\end{array}$ & $\begin{array}{c}\text { Понятия, образую- } \\
\text { щие информацион- } \\
\text { ное пространство } \\
\text { текста интерпрети- } \\
\text { руются путем рас- } \\
\text { смотрения условий } \\
\text { их происхождения }\end{array}$ & $\begin{array}{l}\text { Общее предше- } \\
\text { ствует знаком- } \\
\text { ству с частным и } \\
\text { конкретным }\end{array}$ & $\begin{array}{c}\text { Обнаружение } \\
\text { исходной и } \\
\text { всеобщей связи, } \\
\text { определяющей } \\
\text { содержание и } \\
\text { структуру всего } \\
\text { объекта данных } \\
\text { понятий }\end{array}$ & $\begin{array}{c}\text { Представление } \\
\text { связи в «чистом } \\
\text { виде», в виде бук- } \\
\text { венных формул, в } \\
\text { знаковых моделях }\end{array}$ \\
\hline
\end{tabular}

Табл. 4.

\section{Эмпирические критерии понимания экзистенциальной сферы бытия}

\begin{tabular}{|c|c|c|c|c|c|c|}
\hline \multirow[b]{2}{*}{$\begin{array}{c}\text { Этапы } \\
\text { обучения }\end{array}$} & \multicolumn{6}{|c|}{ Эмпирические критерии } \\
\hline & $\begin{array}{c}\text { Выявление импли- } \\
\text { цитных (скрытых, } \\
\text { неочевидных) } \\
\text { признаков, связей, } \\
\text { закономерностей }\end{array}$ & $\begin{array}{c}\text { Конструиро- } \\
\text { вание новых } \\
\text { представлений } \\
\text { и идей }\end{array}$ & $\begin{array}{c}\text { Фиксирование } \\
\text { чувствительности к } \\
\text { контексту и готов- } \\
\text { ность порождать } \\
\text { контексты в условиях } \\
\text { их отсутствия }\end{array}$ & $\begin{array}{c}\text { Осуществление } \\
\text { варьирующих и } \\
\text { альтернативных } \\
\text { интерпретаций }\end{array}$ & $\begin{array}{l}\text { Осуществление } \\
\text { понимающего } \\
\text { и прогнозиру- } \\
\text { ющего чтения }\end{array}$ & $\begin{array}{c}\text { Создание ав- } \\
\text { торских текстов } \\
\text { (ментальных нар- } \\
\text { ративов) разной } \\
\text { степени сложности }\end{array}$ \\
\hline
\end{tabular}


образы и знаки, присвоенные конкретным человеком, через их уникальную трансформацию во внутреннем психологическом поле становятся тем реальным основанием сигнификативной функции сознания, с помощью которой выстраивается эмоционально-волевая сфера человека, его ценностные ориентации и способность к творческим достижениям» ${ }^{18}$. «...Образы и знаки, создаваемые в истории человечества, формируют некие системы, которые предшествуют каждому отдельному человеку, образуя реальность человеческого бытия. Культура содержит в себе образно-знаковых системы, которые предшествуют отдельному человеку, и навязывают себя ему как объективную реальность, выступающую условием человеческого бытия» ${ }^{19}$. Реальность образно-знаковых систем как достояние человека поднимает его на небывалую высоту в неоспоримых возможностях в отношении с природой, с предметным миром, с человечеством, с самим собой ${ }^{20}$. «...Человек как личность, отражающая условия развития и бытия в реальности образно-знаковых систем, становится способным: творить и вводить новые виды образов, знаков, законов и смыслов; определять линию своего жизненного пути; осуществлять самостоятельный выбор и многое другое» ${ }^{21}$. Реальность образно-знаковых систем - это потенциально бесконечные условия для вариативности человеческого поведения, но это и проницательное, взыскующее око общественного самосознания человечества. Реальность образно-знаковых систем, безусловно, выступает как условие психического развития на всех его возрастных этапах. Эта реальность может стать средством заявления человека о себе как о личности.

Речь идет не о пафосе провозглашения себя в качестве личности, а о том содержании монологической или диалогической речи, в котором проясняется позиция конкретного человека в отношении к другому человеку, к миру людей в целом, к самому себе. Тогда слушающие слышат, смотрящие видят и верят, что этот человек не сойдет с избранного пути, ему достанет силы духа, чтобы не изменить тому, о чем он так убедительно говорит» ${ }^{22}$.

\footnotetext{
18 Там же.

19 Там же.

20 Там же.

21 Там же.

22 Там же.
}

В концептуальных подходах В.В.Знакова, являющихся методологическим основанием для проводимого нами исследования по изучению понимания в обучении, реальность образно-знаковых систем имеет свои особенности и характеристики. Согласно точке зрения В.В. Знакова, эмпирическая реальность воспринимается и понимается людьми как совокупность фактов, допускающих опытную проверку. Внутри герменевтической традиции (герменевтической реальности) доминирует ценностно-смысловую интерпретацию действительности. «Применительно к пониманию это означает, что при его анализе на передний план выступают не достоверные знания о понимаемом объекте, а ценностное отношение к нему. Последнее определяет субъективный характер интерпретации фактов, событий, ситуаций, т.е. ее зависимость от личностного знания, опыта, пристрастий и точек зрения» ${ }^{23}$.

В ходе специально организованной деятельности педагог осуществляет смещение фокуса внимания студентов с описания фактов на анализ событий. При этом нами учитывается, что интерпретация - это непременный атрибут социокультурной реальности и ведущий метод исследования в гуманитарных науках, в частности, в герменевтической традиции научного анализа знания.

«Экзистенциальная реальность человеческого бытия основана на таком единстве познания и переживания, в результате которого порождается опыт, имеющий смысл для субъекта. Экзистенциальная реальность включает в себя ценности людей, а также их духовный мир, который трудно выразить словами и описать в категориях достоверного знания. В современной психологии большое внимание уделяется анализу событий и феноменов, которые нельзя понять только на основе рационального знания, когнитивного и ментального опыта. Важным условием понимания становится актуализация экзистенциального опыта понимающего субъекта...

На экзистенциальном уровне понимание оказывается не столько одной из познавательных процедур (наряду с объяснением, предсказанием и др.), сколько способом бытия человека в мире, дающим ему возможность связывать различные типы знания через неявное знание» ${ }^{24}$.

23 Знаков В.В. Три традиции психологических исследований - три типа понимания // Вопросы психологии. 2009. № 4. С. 19-20.

24 Там же. 


\section{Потенциал интеллекта}

При этом В.В. Знаковым отмечаются следующие факты:

«1. Понимание-знание возникает у субъекта тогда, когда понимание основано преимущественно на оценках истинности высказываний о фактах, событиях, ситуациях.

2. Понимание-интерпретация возникает тогда, когда бессмысленно оценивать истинность высказываний, понимаемых людьми в коммуникативных ситуациях.

Такие суждения являются мнениями, в которых присутствуют и объективные и субъективные компоненты. Мнения можно характеризовать только как правильные или неправильные. В основе квалификации высказывания как правильного лежит согласованное мнение людей о должном, о правилах и нормах поведения. «Правильность» и «неправильность» никогда не бывают абсолютными, они возникают в результате согласования мнений многих людей и зависят от способов интерпретации. В соответствии с принципом когерентности в герменевтической традиции высказывания о мире человека должны быть непротиворечиво согласованными с ранее установленными теоретическими положениями и эмпирическими утверждениями, относящимися к тому же фрагменту реальности» ${ }^{25}$. При этом «с психологической точки зрения интерпретация - это способ понимания, порождения субъектом смысла понимаемого. Понимание всегда включает в себя потенциальную возможность разных типов интерпретации содержания понимаемого, т.е. рассмотрения его с разных точек зрения. Неудивительно, что понимание одних и тех же высказываний в диалоге, текстов, социальных ситуаций оказывается неодинаковым при их интерпретировании преимущественно на основе знаний, установок автора или читателя, говорящего или слушающего ${ }^{26}$.

3. Понимание-постижение. Экзистенциальная традиция исследования психической реальности проявляется в направленности ученых на анализ вариантов порождения опыта, имеющего смысл для субъекта. В жизни каждого человека бывают периоды экзистенциальных размышлений, связанных с пониманием себя в реальных ситуациях человеческого бытия.

В бытийном плане смысложизненные ориентации имеют для каждого из нас не только

25 Там же. конкретное адаптационное значение, но и более глубокий экзистенциальный смысл. К «пониманию себя в мире», «экзистенциальным размышлениям о себе» субъект приходит благодаря ретроспективному и антиципирующему интересу к своему внутреннему миру. Он направлен на поиск смысла своего существования, поступков и мысленный выход за пределы не только конкретной коммуникативной ситуации, но и собственной жизни, включение ее в иную систему координат, в которой жизнь наделяется смыслом» ${ }^{27}$.

Кроме того, особый интерес представляет для нас изучение М.А. Холодной существования особой психической реальности - концептуальных структур (концептов) как психических носителей свойств понятийного мышления.

М.А. Холодная отмечает, что «на современном этапе развития психологии следует говорить о становлении онтологической парадигмы, ориентирующей психологическое исследование на изучение психических структур с соответствующим пересмотром категориального аппарата и разработкой новых методов исследования» ${ }^{28}$. Исследователь допускает существование трех типов понятийных способностей, «таких как семантические способности (усвоение, хранение и актуализация содержания вербальных и невербальных знаков, опосредующих понятийную познавательную деятельность), категориальные способности (выделение и преобразование в системе категориальных признаков, обеспечивающих обобщенную форму познавательного отражения) и концептуальные способности (порождение новых ментальных содержаний, в том числе выявление скрытых связей, конструирование альтернативных интерпретаций, создание авторских нарративов и т.д., что характеризует продуктивный характер понятийного мышления)» ${ }^{29}$. М.А. Холодная описала концептуальные способности, которые ранее в современной психологии не были представлены.

М.А. Холодная называет различные виды понятийной познавательной деятельности, кото-

\footnotetext{
27 Там же.

28 Холодная М.А. Психология понятийного мышления: От концептуальных структур к понятийным способностям. М.: Изд-во «Институт психологии РАН», 2012. С. 223-226.

29 Там же.
} 
рые могут быть инициированы особым, «порождающим» типом понятийных способностей, в том числе: решение абстрактных проблем на основе использования символической системы (прежде всего языковых знаков); понимание проблемы за счет объединения разных частей и разных подходов в единую картину (широкий, целостный взгляд на происходящее); выявление скрытых элементов, признаков, закономерностей, а также готовность устанавливать связи между очевидно не связанными либо отдаленными элементами; выявление ключевого (критического для понимания) признака или аспекта сложной ситуации; использование рассуждений для модификации ранее усвоенных понятий, изменение порядка выводов, создание продуктивных комбинаций понятий; построение варьирующих интерпретаций, в том числе альтернативных; стремление усовершенствовать идеи и процедуры; открытость новому опыту, чувствительность к полезными «невозможным» идеям» ${ }^{30}$.

Именно данные виды понятийной познавательной деятельности, которые инициированы особым, «порождающим» типом понятийных способностей могут представлять, с нашей точки зрения, понимание - постижение.

Достаточно близко соотносятся с исследуемым нами в процессе обучения студентов пониманием - постижением концептуальные способности человека.

Концептуальные способности, согласно М.А. Холодной, - это психические свойства, имеющие отношение к продуктивности процессов концептуализации и обеспечивающие возможность порождения некоторых новых ментальных содержаний, не представленных в актуальных внешних обстоятельствах и отсутствующих в усвоенных индивидуальных знаниях. Таким образом, как подчеркивает М.А. Холодная, «мы имеем дело с принципиально новым - порождающим типом интеллектуальных способностей. Эмпирические критерии концептуальных способностей: 1) выявление имплицитных (скрытых, неочевидных) признаков, связей, закономерностей; 2) конструирование новых представлений и идей, включая концептуальные метафоры; 3) чувствительность к контексту и готовность порождать контексты в условиях их отсутствия; 4) интерпретации, в том числе варьирующие и альтернативные; 5) понимающее и прогнозирующее чтение; 6) создание авторских текстов (ментальных нарративов разной степени сложности)» ${ }^{31}$.

Кроме того, М.А. Холодная представляет самую существенную функцию понятийного мышления (понятийных способностей), которая связана с принципиальным расширением возможностей познающего субъекта, и апеллирует к концепции К. Поппера, выделяющего «три мира: физический мир (мир реальных явлений и объектов), субъективный мир (мир личного опыта и состояний сознания) и мир идей, или «третий мир» (мир объективного культурного наследия в виде теорий, проблем, критических рассуждений, интерпретаций, произведений искусства, текстов журналов и книг)» ${ }^{32}$.

И хотя этот «третий мир», согласно утверждению М.А. Холодной, создан людьми с помощью языка, его содержанием является объективное знание. Понятийные способности - это единственное средство связи индивидуального субъекта с «третьим миром» объективного знания (культурным миром человечества)»33.

Исходя из сказанного выше, можно сделать некоторые выводы: в науке накоплен определенный потенциал для разработки теоретико-методологических и прикладных аспектов проблемы формирования и развития понимания в обучении. Результаты анализа существующих источников научной информации позволили выявить высокую актуальность проблематики развития понимания в обучении и острую необходимость практической реализации концептуальных подходов известных отечественных психологов в непосредственном обучении каждого отдельного студента.

\footnotetext{
30 Холодная М.А. Понятийные способности в структуре интеллекта // Человек, субъект, личность в современной психологии. Материалы Международной конференции, посвященной 80-летию А.В. Брушлинского. Том 3 / Отв. ред. А.Л. Журавлев, Е.А. Сергиенко. М.: Изд-во «Институт психологии РАН», 2013. С. 105-106.
}

\footnotetext{
31 Там же.

32 Там же

33 Там же.
} 


\section{Потенциал интеллекта}

\section{Список литературы:}

1. Баксанский O.Е. Руководство процессом познания: Knowledge Management // Философия и культура. 2013. № 3. С. 366-381.

2. Борзова Т.В. Понимание как методологическая проблема социально-гуманитарных наук // Мир науки, культуры, образования. 2012. № 5(36).

3. Борзова Т.В. Теоретические основы психологии понимания в обучении. Хабаровск: Изд-во Дальневосточ. гос. гуманит. ун-та, 2013. 340 с.

4. Грязнова Е.В. Идентификация человека в информационной реальности // Психология и психотехника. 2013. № 4. С. 371-379.

5. Закирова А.Ф. Теоретико-методологические основы и практика педагогической герменевтики. Дисс. ... докт. пед. наук. Тюмень, 2001.

6. Залевская А.А. Текст и его понимание. Тверь: Тверской государственный университет, 2001. 177 c.

7. Знаков В.В. Понимание в мышлении, общении, человеческом бытии. М.: Изд-во «Институт психологии РАН», 2007. 479 с.

8. Знаков В.В. Три традиции психологических исследований - три типа понимания // Вопросы психологии. 2009. № 4.

9. Леонтьев Д.А. Психология смысла: природа, строение и динамика смысловой реальности. 2-е, испр. изд. М.: Смысл, 2013. 487 с.

10. Мухина В.С. Личность: Мифы и реальность (Альтернативный взгляд. Системный подход. Инновационные аспекты). Екатеринбург: ИнтелФлай, 2007. 1072 с.

11. Петригина В.А. Прагматическая педагогика Дж. Дьюи // Педагогика и просвещение. 2013. № 4. С. 326-335.

12. Слободчиков В.И. Антропологические перспективы отечественного образования. Екатеринбург: Информационно-издательский отдел Екатеринбургской епархии, 2010.

13. Слободчиков В.И., Исаев Е.И. Основы психологической антропологии. Психология развития человека: Развитие субъективной реальности в онтогенезе: учебное пособие для вузов. М.: Школьная пресса, 2000.

14. Сокольников А.М. Мобильное обучение: проблемы и перспективы развития // NB: Кибернетика и программирование. 2013. № 6. С. 28-34. (http://www.e-notabene.ru/kp/article_9668.html).

15. Урсул А.Д. Процесс футуризации и становление опережающего образования // Педагогика и просвещение. 2012. № 2. С. 20-33.

16. Холодная М.А. Понятийные способности в структуре интеллекта // Человек, субъект, личность в современной психологии. Материалы Международной конференции, посвященной 80-летию А.В. Брушлинского. Том 3 / Отв. ред. А.Л. Журавлев, Е.А. Сергиенко. М.: Изд-во «Институт психологии РАН», 2013. $584 \mathrm{c}$.

17. Холодная М.А. Психология понятийного мышления: От концептуальных структур к понятийным способностям. М.: Изд-во «Институт психологии РАН», 2012. 288 с.

\section{References (transliteration):}

1. Baksanskii O.E. Rukovodstvo protsessom poznaniya: Knowledge Management // Filosofiya i kul'tura. 2013. № 3. S. 366-381.

2. Borzova T.V. Ponimanie kak metodologicheskaya problema sotsial'no-gumanitarnykh nauk // Mir nauki, kul'tury, obrazovaniya. 2012. № 5(36).

3. Borzova T.V. Teoreticheskie osnovy psikhologii ponimaniya v obuchenii. Khabarovsk: Izd-vo Dal'nevostoch. gos. gumanit. un-ta, 2013. $340 \mathrm{~s}$.

4. Gryaznova E.V. Identifikatsiya cheloveka v informatsionnoi real'nosti // Psikhologiya i psikhotekhnika. 2013. № 4. S. 371-379.

5. Zakirova A.F. Teoretiko-metodologicheskie osnovy i praktika pedagogicheskoi germenevtiki. Diss. ... dokt. ped. nauk. Tyumen', 2001. 


\section{Психология и психотехника 7(70) • 2014}

6. Zalevskaya A.A. Tekst i ego ponimanie. Tver': Tverskoi gosudarstvennyi universitet, 2001. $177 \mathrm{~s}$.

7. Znakov V.V. Ponimanie v myshlenii, obshchenii, chelovecheskom bytii. M.: Izd-vo "Institut psikhologii RAN", 2007. $479 \mathrm{~s}$.

8. Znakov V.V. Tri traditsii psikhologicheskikh issledovanii — tri tipa ponimaniya // Voprosy psikhologii. 2009. № 4 .

9. Leont'ev D.A. Psikhologiya smysla: priroda, stroenie i dinamika smyslovoi real'nosti. 2-e, ispr. izd. M.: Smysl, 2013. $487 \mathrm{~s}$.

10. Mukhina V.S. Lichnost': Mify i real'nost' (Al'ternativnyi vzglyad. Sistemnyi podkhod. Innovatsionnye aspekty). Ekaterinburg: IntelFlai, 2007. 1072 s.

11. Petrigina V.A. Pragmaticheskaya pedagogika Dzh. D’yui // Pedagogika i prosveshchenie. 2013. № 4. S. 326335.

12. Slobodchikov V.I. Antropologicheskie perspektivy otechestvennogo obrazovaniya. Ekaterinburg: Informatsionno-izdatel'skii otdel Ekaterinburgskoi eparkhii, 2010.

13. Slobodchikov V.I., Isaev E.I. Osnovy psikhologicheskoi antropologii. Psikhologiya razvitiya cheloveka: Razvitie sub"ektivnoi real'nosti v ontogeneze: uchebnoe posobie dlya vuzov. M.: Shkol'naya pressa, 2000.

14. Sokol'nikov A.M. Mobil'noe obuchenie: problemy i perspektivy razvitiya // NB: Kibernetika i programmirovanie. 2013. № 6. S. 28-34. (http://www.e-notabene.ru/kp/article_9668.html).

15. Ursul A.D. Protsess futurizatsii i stanovlenie operezhayushchego obrazovaniya// Pedagogika i prosveshchenie. 2012. № 2. S. 20-33.

16. Kholodnaya M.A. Ponyatiinye sposobnosti v strukture intellekta // Chelovek, sub"ekt, lichnost'v sovremennoi psikhologii. Materialy Mezhdunarodnoi konferentsii, posvyashchennoi 80-letiyu A.V. Brushlinskogo. Tom 3 / Otv. red. A.L. Zhuravlev, E.A. Sergienko. M.: Izd-vo "Institut psikhologii RAN", 2013. 584 s.

17. Kholodnaya M.A. Psikhologiya ponyatiinogo myshleniya: Ot kontseptual'nykh struktur k ponyatiinym sposobnostyam. M.: Izd-vo "Institut psikhologii RAN", 2012. $288 \mathrm{~s}$. 